Article

\title{
The Effect of Biotinylated PAMAM G3 Dendrimers Conjugated with COX-2 Inhibitor (celecoxib) and PPAR $\gamma$ Agonist (Fmoc-L-Leucine) on Human Normal Fibroblasts, Immortalized Keratinocytes and Glioma Cells in Vitro
}

\author{
Łukasz Uram ${ }^{1, *(D)}$, Maria Misiorek ${ }^{1}$, Monika Pichla ${ }^{1}$, Aleksandra Filipowicz-Rachwał ${ }^{2}$, \\ Joanna Markowicz ${ }^{1}$ (D), Stanisław Wołowiec ${ }^{3}$ (D) and Elżbieta Wałajtys-Rode ${ }^{4}$ \\ 1 Faculty of Chemistry, Rzeszów University of Technology, 6 Powstańców Warszawy Ave, 35-959 Rzeszów, \\ Poland; mczygier@prz.edu.pl (M.M.); monika.pichla@live.com (M.P.); j.markowicz@outlook.com (J.M.) \\ 2 Department of Cosmetics and Pharmaceutical Products Technology, \\ Rzeszów University of Information Technology and Management, 2 Sucharskiego Str, 35-225 Rzeszów, \\ Poland; afilipowicz@poczta.wsiz.rzeszow.pl \\ 3 Faculty of Medicine, University of Rzeszów, Warzywna 1a, 35-310 Rzeszow, Poland; swolowiec@ur.edu.pl \\ 4 Department of Drug Technology and Biotechnology, Faculty of Chemistry, Warsaw University of Technology, \\ 75 Koszykowa Str, 00-664 Warsaw, Poland; ewalajtys@ch.pw.edu.pl \\ * Correspondence: luram@prz.edu.pl
}

Academic Editor: Jørn Bolstad Christensen

check for

Received: 1 October 2019; Accepted: 21 October 2019; Published: 22 October 2019

updates

\begin{abstract}
Glioblastoma multiforme (GBM) is the most malignant type of central nervous system tumor that is resistant to all currently used forms of therapy. Thus, more effective GBM treatment strategies are being investigated, including combined therapies with drugs that may cross the blood brain barrier (BBB). Another important issue considers the decrease of deleterious side effects of therapy. It has been shown that nanocarrier conjugates with biotin can penetrate BBB. In this study, biotinylated PAMAM G3 dendrimers substituted with the recognized anticancer agents cyclooxygenase-2 (COX-2) inhibitor celecoxib and peroxisome proliferator-activated receptor $\gamma$ (PPAR $\gamma$ ) agonist Fmoc-L-Leucine (G3-BCL) were tested in vitro on human cell lines with different p53 status: glioblastoma (U-118 MG), normal fibroblasts (BJ) and immortalized keratinocytes (HaCaT). G3-BCL penetrated efficiently into the lysosomal and mitochondrial compartments of U-118 MG cells and induced death of U-118 MG cells via apoptosis and inhibited proliferation and migration at low $\mathrm{IC}_{50}=1.25 \mu \mathrm{M}$ concentration, considerably lower than either drug applied alone. Comparison of the effects of G3-BCL on expression of COX-2 and PPAR $\gamma$ protein and $\mathrm{PGE}_{2}$ production of three different investigated cell line phenotypes revealed that the anti-glioma effect of the conjugate was realized by other mechanisms other than influencing PPAR- $\gamma$ expression and regardless of p53 cell status, it was dependent on COX-2 protein level and high $\mathrm{PGE}_{2}$ production. Similar G3-BCL cytotoxicity was seen in normal fibroblasts $\left(\mathrm{IC}_{50}\right.$ $=1.29 \mu \mathrm{M})$ and higher resistance in HaCaT cells $\left(\mathrm{IC}_{50}=4.49 \mu \mathrm{M}\right)$. Thus, G3-BCL might be a good candidate for the targeted, local glioma therapy with limited site effects.
\end{abstract}

Keywords: biotinylated PAMAM G3 dendrimer; COX-2 inhibitor-celecoxib; PPAR $\gamma$ agonistFmoc-L-Leucine; human fibroblast; glioblastoma and immortalized keratinocytes

\section{Introduction}

Glioblastoma multiforme (GBM), classified by WHO as grade IV, is the most lethal primary tumor of the central nervous system (CNS), with high prevalence in developed, industrialized countries [1,2]. The 
particularly invasive nature of GBM is the main source of recurrence [3]. The present, conventional GBM treatment that includes surgery combined with radiotherapy and chemotherapy with temozolomide (TMZ) has limited clinical efficacy and patient prognosis remains poor with a survival rate of 15 months after diagnosis and 5-year survival of 5\% of patients [4-7].

Among major signaling pathways affected in GBM, the mutation/inactivation of gene p53, a main switch coordinating cell fate between survival and death has been found in $54-87 \%$ of high-grade human gliomas [8-10]. The p53 mutations are associated with short survival time and resistance to chemo and radio therapy and the same mutants are known to gain oncogenic functions and promote tumorigenesis and cancer progression [11,12]. Thus, it is a matter of importance to recognize of the effectiveness of applied therapeutics against cancer cells with modified p53 status as compared with normal or non-cancerogenic immortalized cells with mutated p53.

In the search for effective GBM therapy, new approaches are considered (for a review see [13]). Among them, combined therapies using the small molecule inhibitors of cell signaling pathways that are overexpressed in gliomas are under investigation [14]. Prominent signaling pathways have been recognized that control tumor development, progression and malignancy. The canonical Wnt $/ \beta$-catenin signaling pathway, the COX-2 and peroxisome proliferator-activated receptor gamma (PPAR $\gamma$ ) activities that operate in opposing manner have an impact on regulation of tumor growth, including GBM. It was revealed that in many cancers including gliomas, the $\mathrm{Wnt} / \beta$-catenin pathway and COX-2 expression are upregulated while PPAR $\gamma$ is downregulated [15-18]. The interaction between these pathways is complicated and elicited by various molecular mechanisms. Under normal homeostasis, PPAR $\gamma$ agonists directly inhibit activation of $\beta$-catenin and transcription of $\mathrm{Wnt} / \beta$-catenin targeted genes, including COX-2, that stop cancer development and progression [19]. During cancerogenesis, the overexpression of COX-2 and high level of its metabolite prostaglandin E2 ( $\left.\mathrm{PGE}_{2}\right)$ in GBM cells correlate with a substantial increase of the rate of cell proliferation, adhesion, migration, angiogenesis and metastasis, as well as with immunosuppression of defense mechanisms [20-23]. However, recent data has revealed that there is no simple relation between COX-2 activity and $\mathrm{PGE}_{2}$ level and antitumor action of their inhibitors, due to diverse effects of compounds on cellular metabolism and various signaling pathways [24-26].

Among nonsteroidal anti-inflammatory drugs (NSAIDs) that affect the Wnt/ $\beta$-catenin pathway, celecoxib inhibits $\beta$-catenin signaling by cyclooxygenase (COX-2)-dependent and COX-2-independent mechanisms and has demonstrated anticancer activity [27,28]. COX-2 inhibition decreases cellular levels of fatty acids and their derivatives supplied by the lipooxygenase and cyclooxygenase pathways that are PPAR- $\gamma$ ligands and therefore indirectly affect PPAR- $\gamma$ activity $[29,30]$. On the other hand, COX-2 inhibitors and certain prostaglandins (15d-PGJ2) bind and activate the nuclear receptor PPAR $\gamma$ [31]. It has been also shown that anti-tumor mechanisms of the COX 2 inhibition might be either p53-dependent or p53-independent in various cancerous and non-cancerous cells. In glioma cell lines with active p53, celecoxib effectively inhibits viability and proliferation whereas in lines with inhibited or mutated p53, no induction of apoptosis is observed [32].

Overexpression of PPAR $\gamma$ is also a hallmark of GBM cells [33] and it has been documented that the PPAR $\gamma$ agonists thiazolidinediones and Fmoc-L-Leucine inhibit growth, proliferation, and induce apoptosis in various human glioblastoma cells in vivo, and thus may be regarded as a potential agents for GBM therapy [34-39]. The obvious conclusion is to combine both factors to potentiate anti-glioma effects [31]. So far, the synergistic anti-cancer action of these two factors was shown in in vivo and in vitro studies [40-42]. Also, our earlier study showed additive effects of celecoxib (COX-2 inhibitor) and Fmoc-L-Leucine (PPAR $\gamma$ agonist) conjugated with biotinylated PAMAM G3 dendrimer in glioma and squamous cell carcinoma in vitro [39]. However, a limitation of the described therapy is its toxic side effects. It is known that dependent and independent pro-proliferative effects receptor PPAR $\gamma$ agonists lead to increased risk of cardiovascular disease and peripheral fractures [43-45]. Also, COX-2 inhibitor treatment is associated with an increased risk of adverse cardiovascular events [46]. So, lowering the therapeutic concentrations of described drugs also becomes an important issue [47,48]. 
Particular attention has been given to poly(amidoamine) dendrimers (PAMAM) as drug carriers, due to their beneficial physico-chemical properties and reasonable biocompatibility $[49,50]$. These cationic nanocarriers bearing hydrophilic surfaces have been shown to be suitable for delivering drugs to brain tumors [51,52]. The penetration of the blood brain barrier (BBB) by dendrimers and accumulation in malignant glioma was demonstrated for functionalized dendrimers [53]. Positive results were obtained with PAMAM dendrimers in glioma in vivo imaging [54] and in various types of drug delivery into gliomas [55]. Biotin is considered as a particularly promising ligand that can transfer conjugated drugs across the BBB and target brain tumors [56,57]. Biotin binds to specific surface receptors (Sodium Dependent Multivitamin Transporter, SMVT) or monocarboxylate transporters (MCT-1 and MCT-8) overexpressed in a majority of cancer cells [58-60]. Veszelka et al. (2017) showed that biotin increased transfer of solid nanoparticles (SNP) across brain endothelial hCMEC/D3 cells (BBB model) with expression of mRNA for SMVT (SMVT/SLC5A6) gene. After $8 \mathrm{~h}$ of incubation, uptake of the biotin-SNP was two times higher than the uptake of SNP alone. Also, the permeability of BBB upon biotin-SNP treatment was 2.8-fold higher than that of SNP. Moreover, biotinylated glutathione was shown to increase nanoparticle permeability through endothelial monolayers supporting its use as a brain targeting vector [61]. Also, our earlier studies revealed the usefulness of biotinylated PAMAM G3 dendrimers as a vehicle of perspective anti-glioma drugs (celecoxib and Fmoc-L-Leucine). Biotinylated PAMAM G3 dendrimers substituted with those drugs revealed higher cytotoxicity against U-118 MG glioma cells as compared to single drugs and were delivered more efficiently than non-biotinylated constructs $[39,62]$.

The major aim of this study was to gain more information concerning the possibility of obtaining a nanocarrier with both COX-2 inhibitor and PPAR $\gamma$ agonist, for use as a potential local GBM therapeutic. For this purpose, PAMAM G3 dendrimer was conjugated with 16 celecoxib molecules (COX-2 inhibitor), 15 molecules of Fmoc-L-Leucine (agonist of PPAR $\gamma$ ) and one tumor-targeting biotin molecule (G3-BCL) [39]. To evaluate the cytotoxic effect of the G3-BCL conjugate, three human cell lines with various phenotypes were chosen. Glioblastoma U-118 MG classified as grade IV GBM and immortalized keratinocytes ( $\mathrm{HaCaT}$ ) have confirmed mutations in the p53 gene that generally are characteristic for development of cancer. However, the immortalized HaCaT line is not cancerogenic. For comparison, normal fibroblasts (BJ) with active p53 were also included. The biological properties of G3-BCL conjugate were assessed by determining viability, mechanisms of cell death (apoptosis/late apoptosis-necrosis) and mobility, cellular energy level (ATP), expression of COX-2 and PPAR $\gamma$ proteins and $\mathrm{PGE}_{2}$ production. Intracellular accumulation and localization of a fluorescent labeled G3-BCL analogue were also performed. The results obtained showed that G3-BCL conjugate revealed much higher cytotoxicity and inhibition of mobility of the U-118 MG cells (at 1-4 $\mu \mathrm{M}$ concentration) as compared to either drug applied alone. HaCaT cells exhibited higher resistance to G3-BCL conjugates. The interesting results concern the high mitochondrial localization of investigated conjugate in U-118 MG cells and induction of cell death preferentially by an apoptotic mechanism. Results showed a similar sensitivity of normal fibroblasts to conjugate treatment that limits the application of obtained nanocarrier to localized treatment.

\section{Results and Discussion}

\subsection{Cytotoxicity of G3-BCL Conjugate}

The G3-BCL construct was toxic at a low concentration range for glioma cells $\left(\mathrm{IC}_{50}=1.25 \mu \mathrm{M}\right)$ and normal human fibroblasts $\left(\mathrm{IC}_{50}=1.29 \mu \mathrm{M}\right)$, whereas immortalized keratinocytes were more resistant $\left(\mathrm{IC}_{50}=4.49 \mu \mathrm{M}\right)($ Figure 1). 


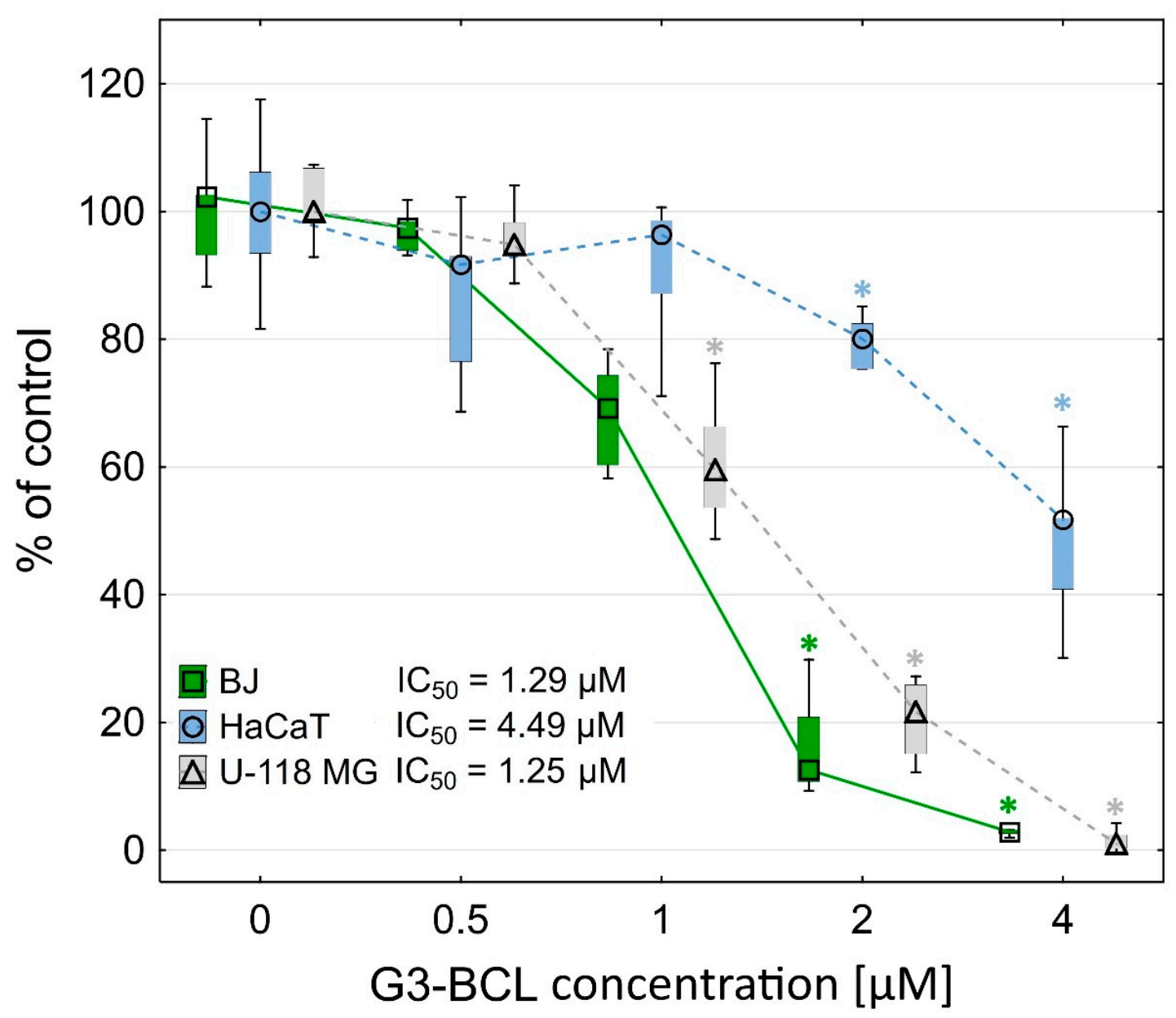

Figure 1. Cytotoxicity of G3-BCL conjugate for BJ, HaCaT and U-118 MG cells after $24 \mathrm{~h}$ treatment, estimated by XTT assay. Results are presented as median of triplicate assays from three independent experiments and expressed as \% of non-treated controls. The whiskers are lower (25\%) and upper $(75 \%)$ quartile ranges. ${ }^{*} \mathrm{P}<0.05 ;$ Kruskal-Wallis test.

\subsection{Proliferation}

Inhibition of proliferation of the fibroblasts by G3-BCL conjugate was observed at a range of $\mathrm{IC}_{50}$ concentration similar to its cytotoxicity. However, in U-118 MG cells, a two-phase effect was seen. At low, non-toxic concentrations (up to $0.25 \mu \mathrm{M}$ ), proliferation rate increased to $120 \%$ of control and significant decrease was visible at $\mathrm{IC}_{50}$ concentration ( $60 \%$ of control). In HaCaT cells, decrease of proliferation rate begun at $0.5 \mu \mathrm{M}$ concentration and at $\mathrm{IC}_{50}$ concentration amounted to $60 \%$ of control (Figure 2). 


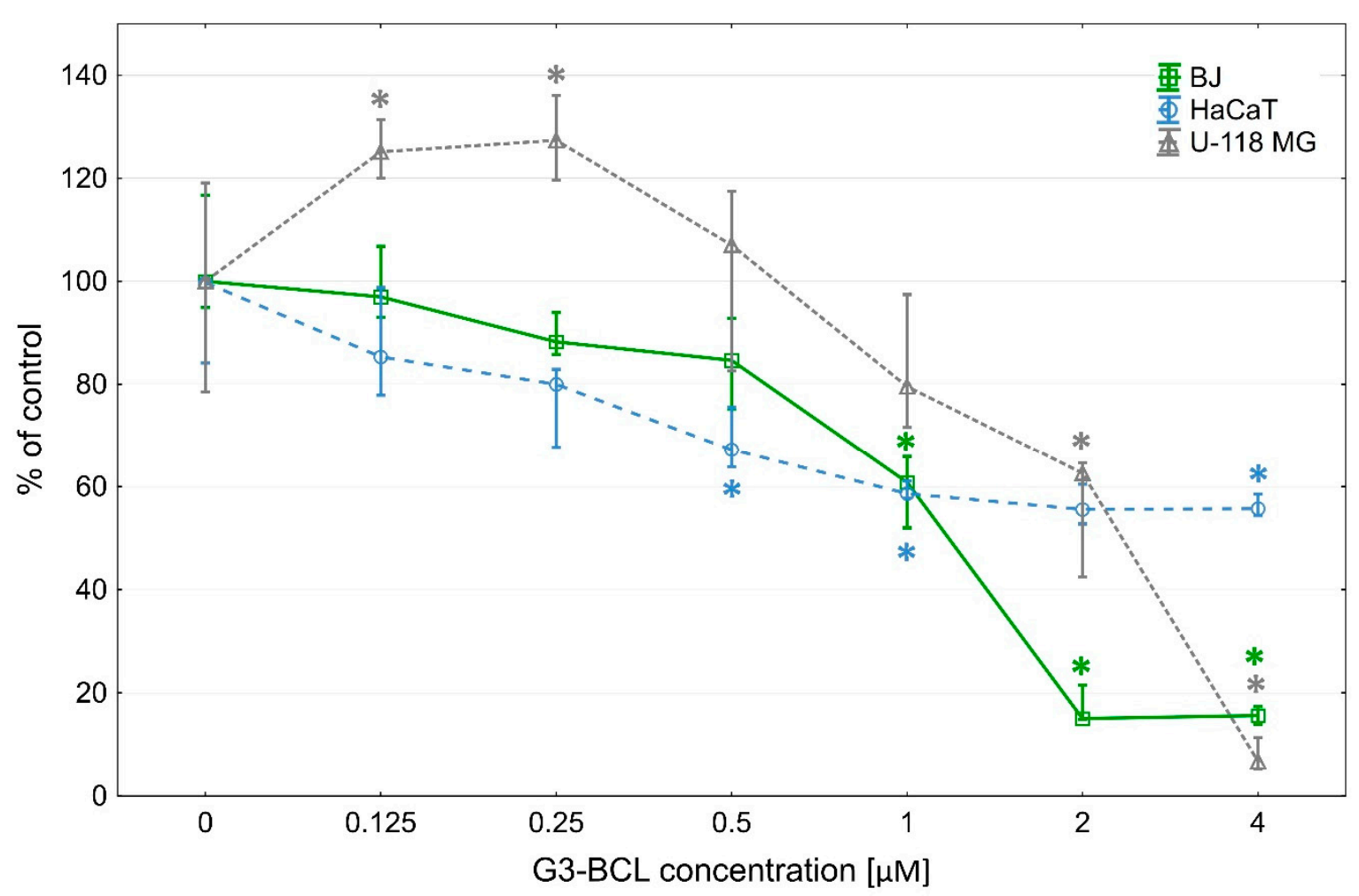

Figure 2. Proliferation of investigated cells after $72 \mathrm{~h}$ incubation with G3-BCL conjugate. Results are presented as median of triplicate from three independent experiments and expressed as \% of non-treated controls. The whiskers are lower (25\%) and upper (75\%) quartile ranges. ${ }^{*} \mathrm{P}<0.05$; Kruskal-Wallis test.

Celecoxib and parecoxib, the prodrug of valdecoxib from the same group as celecoxib, significantly reduced the proliferation of a variety of GBM cell lines, however, at much higher concentrations of 50-100 $\mu \mathrm{M}$ and 100-200 $\mu \mathrm{M}$, respectively [63,64].

\subsection{Cellular Accumulation of G3-BCLF}

Time-dependent uptake of $0.1 \mu \mathrm{M}$ G3-BCLF by fibroblasts reached a steady state after $6 \mathrm{~h}$, whereas both $\mathrm{HaCaT}$ and glioma cells accumulated the conjugate in a concentration-dependent manner up to $24 \mathrm{~h}$; however, this was at a lower level than fibroblasts (Figure 3A and confocal imaging Figure 3B). This observation points to more efficient biotin-conjugate transport into normal fibroblasts as compared to cancer U-118 MG cells and immortalized keratinocytes. This may be due to the described phagocytic activity of fibroblasts [65]. The lower accumulation of G3-BCLF in U-118 MG cells may be the result of the active xenobiotic efflux systems present in cancer cells since our earlier studies revealed similar fluorescent labeled biotin accumulation in BJ, HaCaT and U-118 MG cells assayed under the same conditions [39]. In HaCaT cells, the high detoxifying II phase enzymes activity was found that may be responsible for the observed lower level of G3-BCLF accumulation as compared to fibroblasts [66]. 

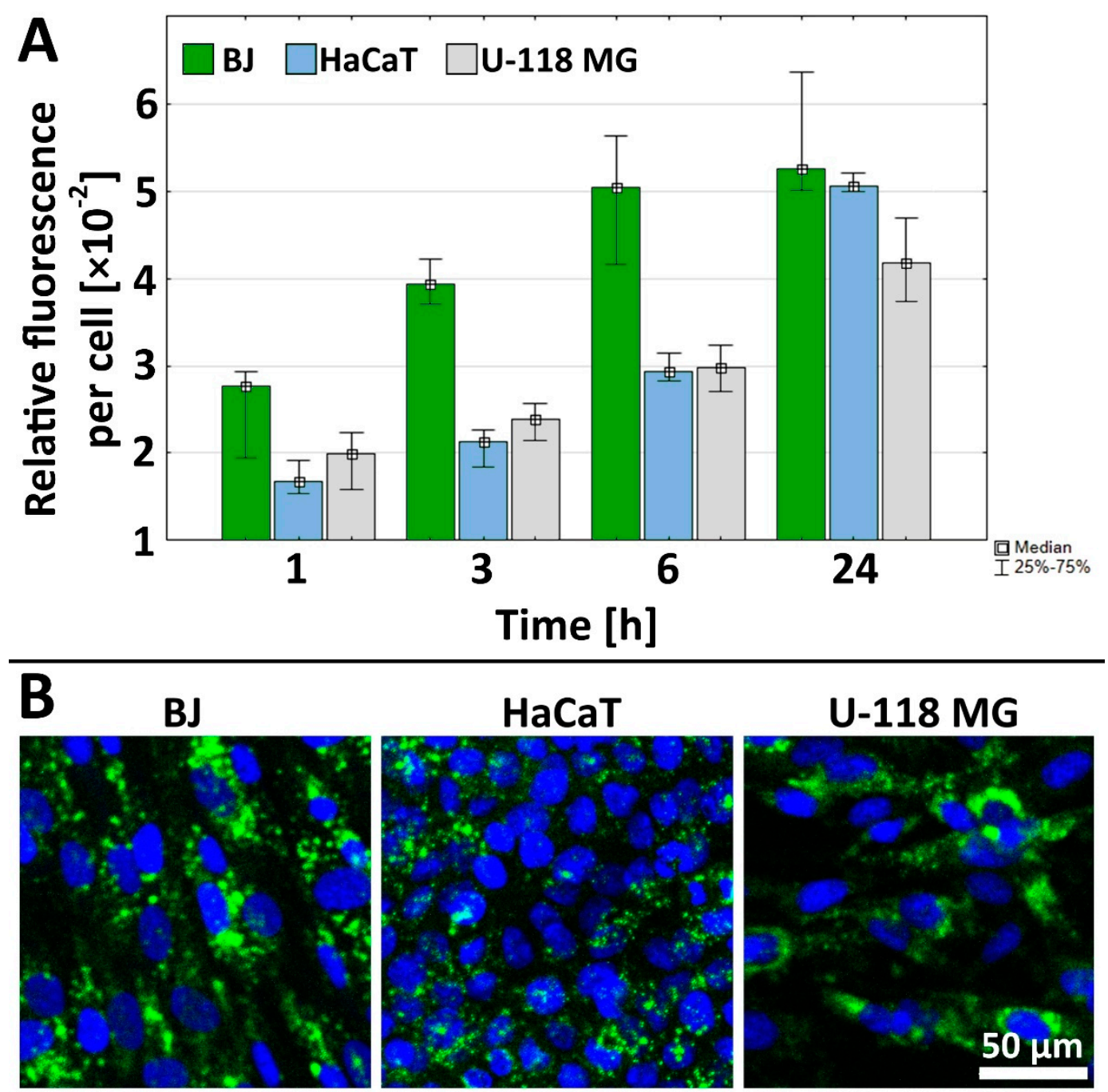

Figure 3. (A) Time-dependent cellular accumulation of $0.1 \mu \mathrm{M}$ G3-BCLF conjugate in BJ, HaCaT and U-118 MG cells. Results are presented as median of triplicate assays from three independent experiments and expressed as a fluorescence signal (relative fluorescence units) per cell. The whiskers are lower (25\%) and upper (75\%) quartile ranges. (B) Representative images of the accumulation of G3-BCLF conjugate after $24 \mathrm{~h}$ incubation (green signal) and DAPI labeled nuclei (blue signal).

\subsection{Subcellular Localization of G3-BCLF}

The subcellular localization of fluorescent G3-BCLF was measured at low, nontoxic $(0.1 \mu \mathrm{M})$ and concentrations equal to $\mathrm{IC}_{50}$ ( $\mathrm{IC}_{50}=1.25,1.29,4.49 \mu \mathrm{M}$ for U-118 MG, BJ and HaCaT, respectively). The estimation of Mander's coefficient (M2) of the G3-BCLF in all investigated cell lines indicated following colocalization efficiency after $24 \mathrm{~h}$ treatment: lysosomes $>$ mitochondria $>$ nuclei (Figure 4A,B). The M2 coefficient for lysosomal localization revealed similar and a rather high value $>0.6$ at $\mathrm{IC}_{50}$ concentrations for all investigated cell lines. Studies with confocal laser scanning microscopy revealed that unmodified and surface modified G3 PAMAM dendrimers are internalized and trafficked to endosomes and lysosomes [67]. High levels of G3-BCLF in lysosomes may indicate active macropinocytosis or clatrin-mediated endocytic transport of conjugate [68]. Also, Albertazzi et al. showed that cationic and neutral PAMAM dendrimers are internalized through clathrin-dependent endocytosis and macropinocytosis, with cargo redirected into the lysosomes (high degree of colocalization coefficient) [69]. Kitchens et al. indicated that PAMAM dendrimer internalization was realized via endocytosis pathway with vesicular trafficking and clathrin-dependent endocytosis $[70,71]$. The 
G3-BCL dendrimer in this study might also be internalized partially by biotin receptor-mediated endocytosis or charge-mediated adsorptive endocytosis. Yellepeddi et al. showed that in ovarian cancer (OVCAR-3) and human embryonic kidney (HEK 293T) cells cellular uptake of biotin-PAMAM G4 dendrimers occurred as described above [72]. It is also possible that celecoxib and Fmoc-L-Leucine residues attached to the surface of biotinylated PAMAM molecule have an impact on the internalization pathway and distribution of the tested compound in the cell. However, this issue requires further and more detailed research.
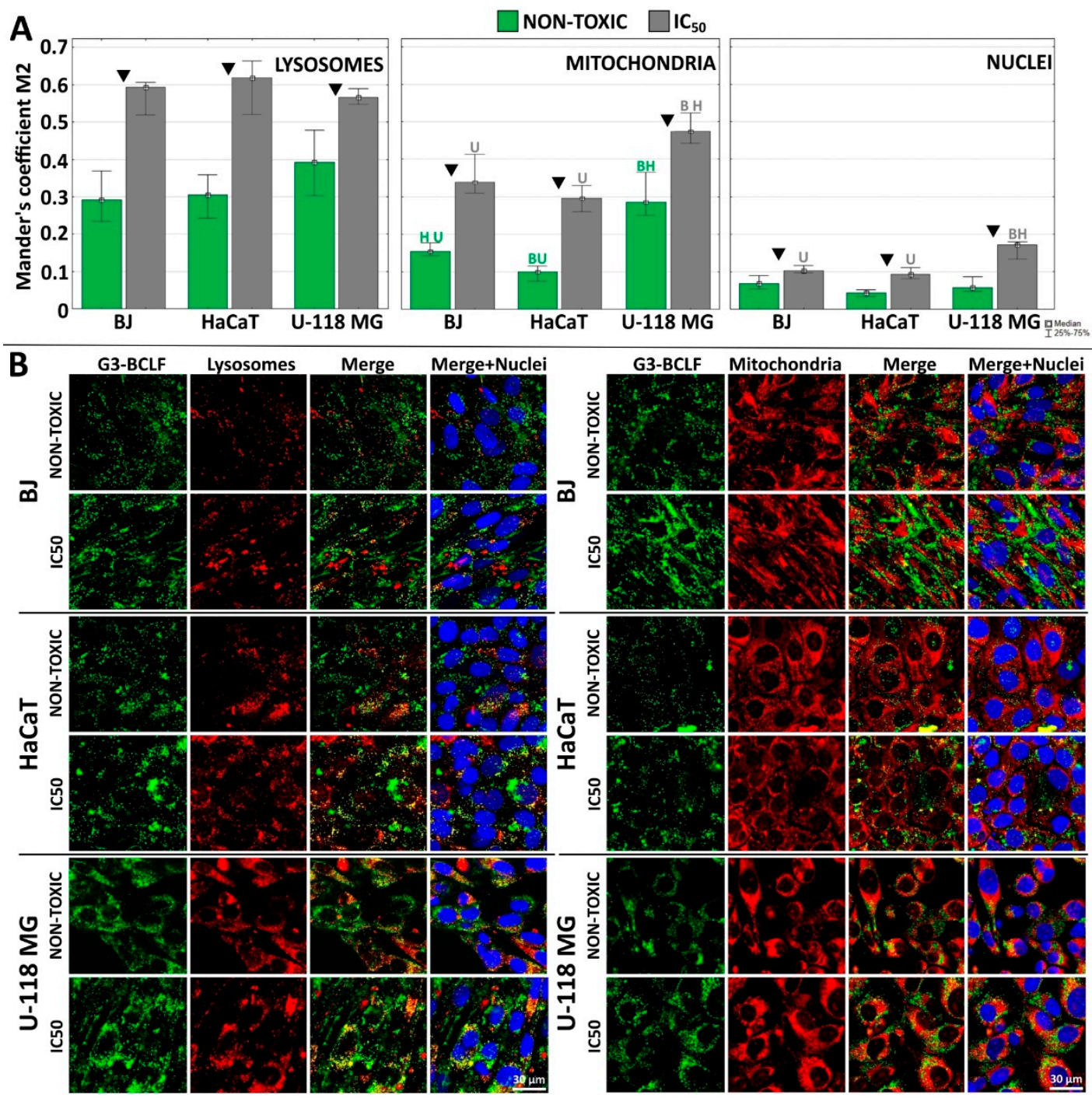

Figure 4. (A) Localization of G3-BCLF in lysosomes, mitochondria and nuclei of BJ, HaCaT and U-118 MG cells after $24 \mathrm{~h}$ incubation at low, non-toxic $(0.1 \mu \mathrm{M})$ and equal to $\mathrm{IC}_{50}$ concentrations. Results are medians of twelve images measurement from each experimental group and expressed as Mander's coefficient. The whiskers are lower $(25 \%)$ and upper $(75 \%)$ quartile ranges. Letters indicate significant differences between cell lines (each letter indicate cell line), $\mathrm{P}<0.05$; Kruskal-Wallis test. $\mathbf{P}<0.05$; Mann-Whitney U-test (non-toxic against $\mathrm{IC}_{50}$ concentration). (B) Confocal images presenting colocalization of G3-BCLF within lysosomes, mitochondria and nuclei in investigated cell lines. Green signal: G3-BCLF, red: lysosomes (left panel) or mitochondria (right panel), blue: DAPI stained nuclei, yellow: overlapping signal from G3-BCLF and lysosomes or mitochondria. Scale bar equal $30 \mu \mathrm{m}$.

The nuclear envelope proved to be a barrier for the conjugate. At non-toxic concentrations of G3-BCLF, Mander's coefficient did not exceed the value 0.07 in all cell lines and at $\mathrm{IC}_{50}$ concentrations, 
the M2 value was $<0.2$ in glioma and $<0.1$ in $\mathrm{BJ}$ and $\mathrm{HaCaT}$ cells (Figure $4 \mathrm{~A}$ ). This is in good agreement with data obtained by the others concerning cellular biotin localization [73]. Most interesting is a high localization of G3-BCLF in mitochondria of U-118 MG cells. M2 at non-cytotoxic concentration was 0.28 and at concentration equal to $\mathrm{IC}_{50}$, increased to 0.47 and was significantly higher than M2 values estimated for $\mathrm{BJ}(0.17$ and 0.33$)$ and $\mathrm{HaCaT}(0.10$ and 0.33$)$, respectively. This points to the possible action of G3-BCLF within mitochondria of glioblastoma cells. This is particularly important since recently, mitochondria has become a promising target of anticancer therapy. It has been confirmed that cancer transformation is accompanied by the deregulation and disruption of many crucial mitochondrial functions. Recognized hallmarks of cancer such as uncontrolled proliferation, disabled apoptosis, acquired migration (invasiveness) and primarily switch in energy metabolism from ox-phosph to glycolytic pathway depend on deregulations of respective mitochondrial signal transduction pathways (for a review see [74]). It has been shown that celecoxib and PPAR $\gamma$ agonists exert influence on the mitochondria-dependent apoptosis and metabolism [75,76]. The high cytotoxic effect of G3-BCL in glioma and BJ cells may be explained by the observation that it was accumulated at a higher level in mitochondria of these cells as compared with $\mathrm{HaCaT}$ mitochondria (Figure 4).

\subsection{Intracellular ATP Level}

Estimation of cellular ATP level revealed that PAMAM G3-BCL conjugate at $0.5-2 \mu \mathrm{M}$ concentrations did not significantly affect the level of nucleotide, and the energy homeostasis remained stable in all investigated cell lines. However, at cytotoxic concentrations higher than $4 \mu \mathrm{M}, \mathrm{BJ}$ cells were depleted of ATP and dead, whereas in both HaCaT and glioma cells, a significant increase of ATP level was observed of up to $150 \%$ and $180 \%$ of the control, respectively (Figure 5). This generation of energy in glioma cells may be explained by the effective switch from OX-PHOS mechanisms to the glycolytic pathway characteristic of cancer cells [74].

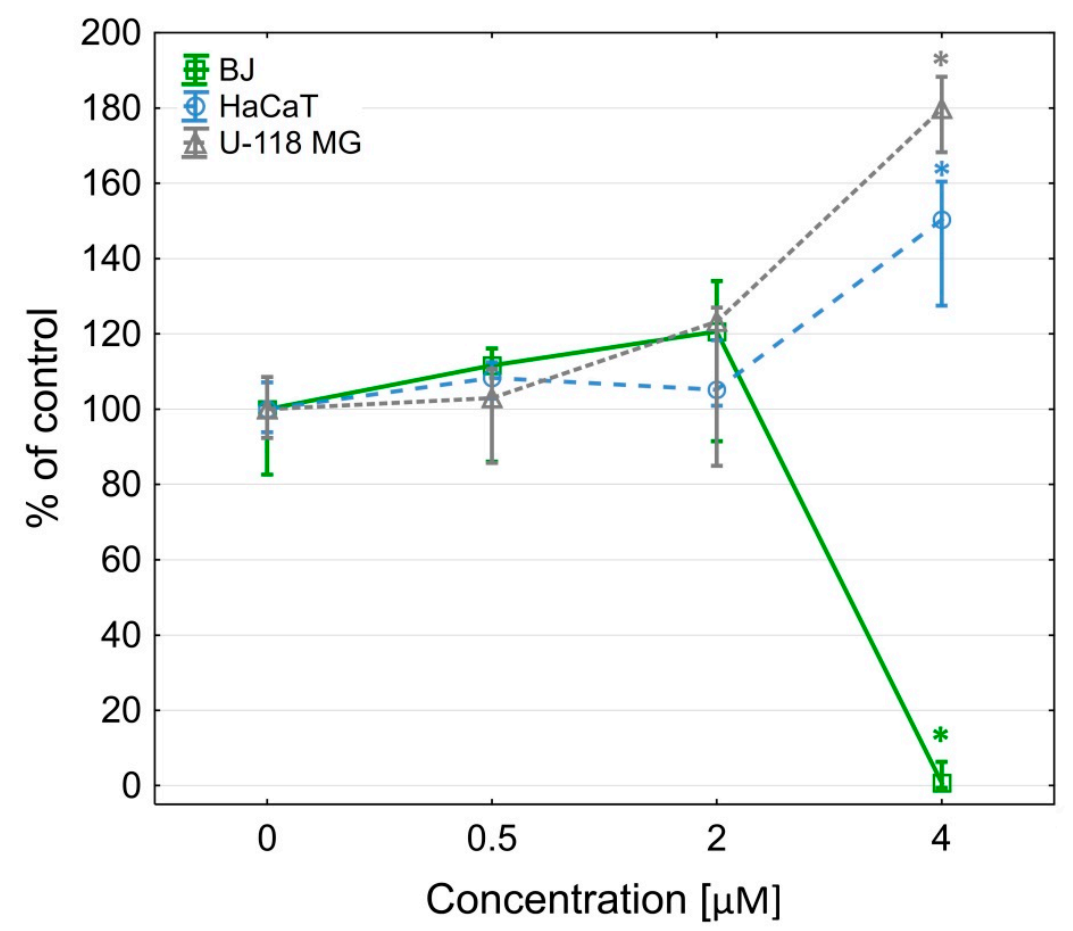

Figure 5. Intracellular ATP level in BJ, HaCaT and U-118 MG cells after $24 \mathrm{~h}$ treatment with G3-BCL. Results are presented as median of triplicates from three independent experiments and expressed as $\%$ of non-treated controls. The whiskers are lower $(25 \%)$ and upper $(75 \%)$ quartile ranges. ${ }^{*} \mathrm{P}<0.05$ (Kruskal-Wallis test). 


\subsection{Apoptosis and Late Apoptosis/Necrosis}

A very different profile of caspase $3 / 7$ activity as marker of apoptosis (A) [77] and penetration of 7-ADD into cells as a marker of late apoptotic/necrotic $(\mathrm{LA} / \mathrm{N})$ phase [78] were seen in the investigated cell lines. It has been established that intracellular levels of ATP, supplied through glycolysis or oxidative phosphorylation, determines cell death by apoptosis, favored by a high level of intracellular ATP or necrosis, promoted by low energy level $[79,80]$. Fibroblasts enter the apoptotic pathway measured as caspases $3 / 7$ activity at non-toxic $0.5 \mu \mathrm{M}$ G3-BCL concentration with significant increase up to $2 \mu \mathrm{M}$ concentration (in the range of $\mathrm{IC}_{50}$ value) with constant ATP supply. At $4 \mu \mathrm{M}$ conjugate, a significant increase of LA/N was observed that correlates with depleted cellular ATP level (Figure 6) [81]. It has been shown by others that in fibroblasts, the effector caspase activation caused poly(ADP-ribose)polymerase-1 (PARP-1) cleavage with maintained ATP level and induction of apoptosis [82]. Similarly, in glioma cells, the increase of caspases $3 / 7$ activity and induction of apoptosis was dominant up to $2 \mu \mathrm{M}$ (in range of $\mathrm{IC}_{50}$ ) concentration, whereas the change to LA/N processes was seen at $4 \mu \mathrm{M}$ concentration despite of high cellular ATP level. However, those markers were at a much lower level than in fibroblasts (Figure 6). The propensity of astrocytic glioma to necrosis was described by Furnari et al. [83].

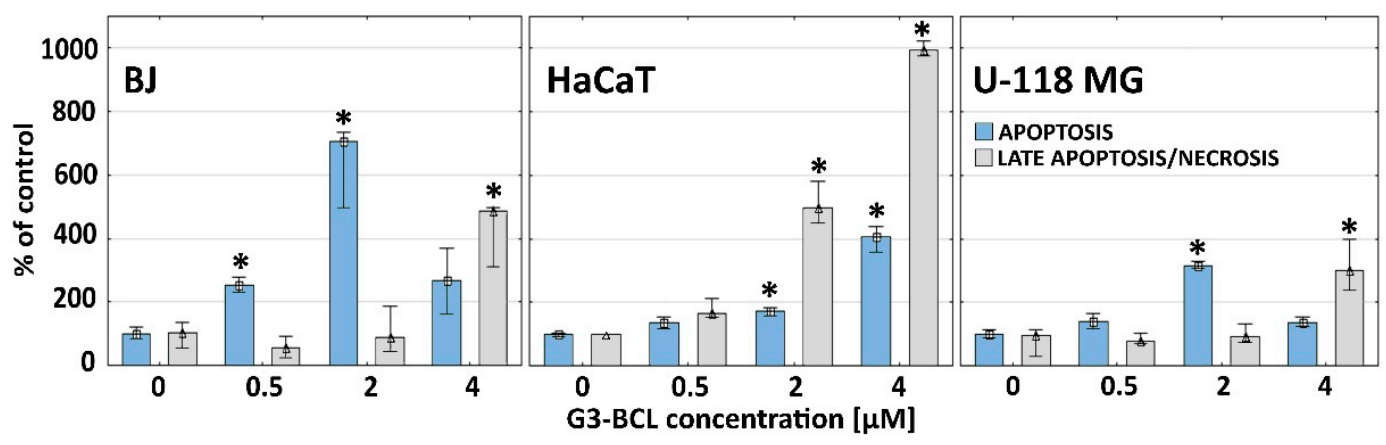

Figure 6. Caspase 3/7 activity and late apoptotic/necrotic cell population in BJ, HaCaT, and U-118 MG cells after $24 \mathrm{~h}$ treatment with G3-BCL conjugate. Results are medians of triplicate from three independent experiments expressed as \% of the non-treated controls. The whiskers are lower (25\%) and upper $(75 \%)$ quartile ranges. ${ }^{*} \mathrm{P}<0.05$ (Kruskal-Wallis test).

In $\mathrm{HaCaT}$ cells, which were most resistant to G3-BCL cytotoxicity, a higher participation of LA/N was seen from $2 \mu \mathrm{M}$ concentration as compared to low level of apoptotic marker, caspases 3/7 activity, despite of high ATP level. Similar observations were obtained by Nzengue, et al. [84] who investigated the mechanism of cell death in HaCaT keratinocytes and rat glioma C6 cells. The resistance of HaCaT cells to apoptosis was also described by other authors, who have shown that many effectors which induce apoptosis in other cell types did not affect $\mathrm{HaCaT}$ keratinocytes. Of the tested stimuli including interferon gamma, tumor necrosis factor alpha, interleukin-4 and muramyl dipeptide, only interferon gamma induced $\mathrm{HaCaT}$ cell apoptosis $[85,86]$. This may be explained by spontaneous mutations in both alleles of pro-apoptotic protein p53 in immortalized HaCaT cells that affect the apoptosis pathway $[87,88]$ and may also increase this cell line resistance to the G3-BCL construct.

Similar viability and apoptotic/necrotic response of BJ and glioma cells to conjugate treatment and a different pattern of $\mathrm{HaCaT}$ response indicate that composed action of both drugs on induction of cell death mechanisms was independent on $\mathrm{p} 53$ status. It has been shown that celecoxib alone caused no significant difference in apoptosis level independent of p53 status of various tested glioma cell lines [32]. 


\subsection{Effect of G3-BCL on Cell Migration}

G3-BCL conjugate at concentrations in the range below $\mathrm{IC}_{50}(1 \mu \mathrm{M})$ decreased GBM and human fibroblast cells mobility significantly (to $45 \%$ and $40 \%$ of controls, respectively) and a decrease of migration rate at $2 \mu \mathrm{M}$ concentration was seen in $\mathrm{HaCaT}$ cells (to $70 \%$ of control) (Figure 7).
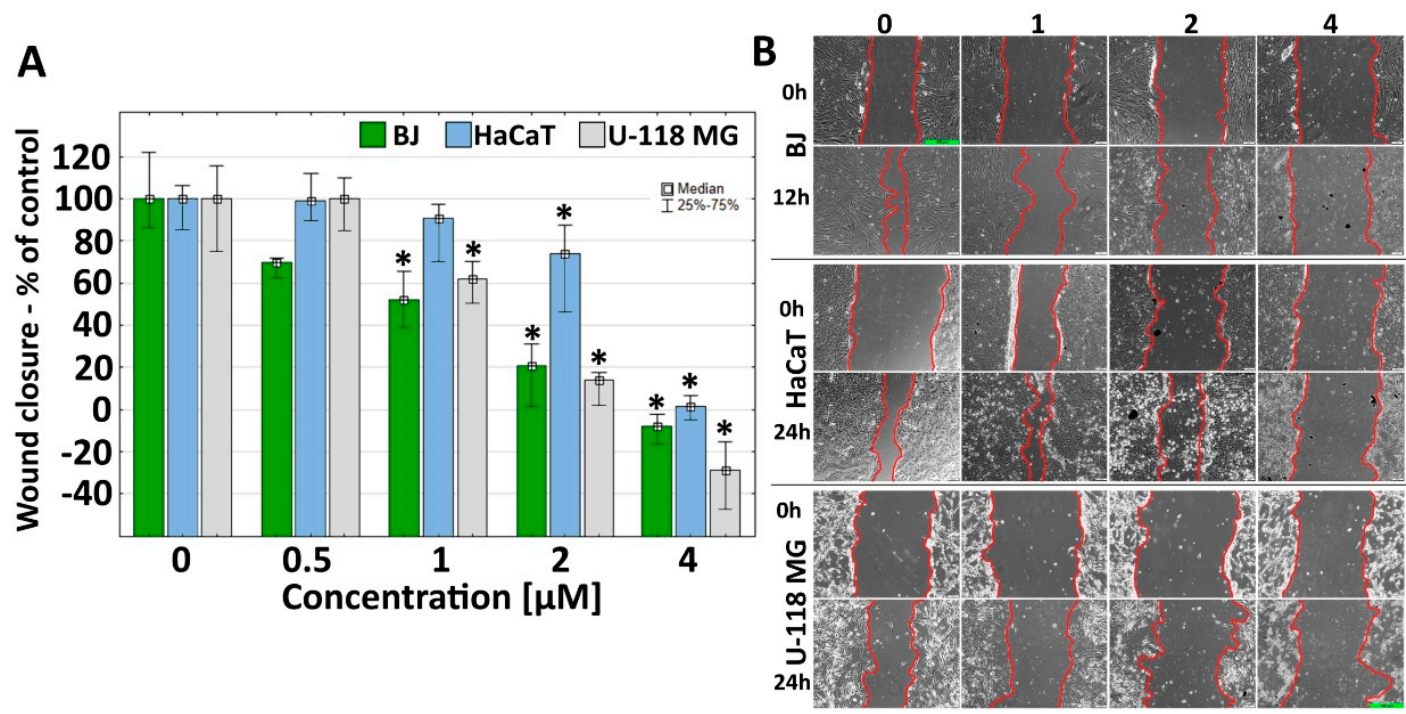

Figure 7. (A) G3-BCL effect on BJ, HaCaT, and U-118 MG cell migration after 12 and $24 \mathrm{~h}$ treatment. Results are presented as median of triplicate from three independent experiments and expressed as \% of non-treated controls. The whiskers are lower (25\%) and upper (75\%) quartile ranges. ${ }^{*} \mathrm{P}<0.05$; (Kruskal-Wallis test). (B) Images from contrast-phase inverted microscope. Scale bar equal to $300 \mu \mathrm{m}$.

The anti-migration property of G3-BCL was visible only at cytotoxic concentrations estimated with an XTT assay (Figure 1). At $2-4 \mu \mathrm{M}$, dendrimer concentration for BJ and HaCaT cells, and 1-4 $\mu \mathrm{M}$ for U-118 MG, inhibition of cells migration was caused by toxic and anti-proliferative effect of the tested compound. This was also confirmed by apoptosis and late apoptosis/necrosis occurrence at the mentioned dendrimer concentrations. Anti-migratory activity of celecoxib was observed in various cancer cell lines at clinically achievable concentrations (2.5-5.0 $\mu \mathrm{M})$ [89-92]. In human glioblastoma SHG-44 cells the anti-metastatic effect of celecoxib was observed at 30-150 $\mu \mathrm{M}$ concentration [93]. Parecoxib, the prodrug of valdecoxib the COX-2 antagonist from the same group as celecoxib, inhibits in vitro GBM cell proliferation, migration and invasion at concentrations of 50-100 $\mu \mathrm{M}$ [64]. In addition, increasing evidence suggests that PPAR $\gamma$ agonists, including thiazolidinediones and nonthiazolidinediones, inhibit the motility and invasiveness of glioma cells [94]. Very invasive behavior of GBM is characteristic for that cancer [3,95], hence the observed anti migratory effect of G3-BCL conjugate at much lower concentration than either drug alone may efficiently prevent or limit of the GBM penetration into surrounding tissues.

\subsection{COX-2 Expression and $P G E_{2}$ Production}

All investigated cell lines exhibited a basal level of COX-2 protein expression and production of $\mathrm{PGE}_{2}$ (Figure 8). It has been confirmed that in fibroblasts, the level of COX-2 protein was very low and significantly higher levels were seen in U-118 MG cells. In addition, non-stimulated HaCaT cells presented higher levels of COX-2 as compared to normal BJ cells (Figure 8). The observation that high COX-2 expression correlated with glioma histological grade but not with positive p53 immunostanning was made by Shono et al. [20].

The G3-BCL conjugate at non-cytotoxic and at $\mathrm{IC}_{50}$ concentrations induced a conventional response in $\mathrm{BJ}$ cells with a significant increase of COX-2 expression, without effecting $\mathrm{PGE}_{2}$ production. In U-118 MG cells, a concentration-dependent effect on COX-2 protein level was observed; inhibition 
at low, non-cytotoxic and up-regulation at $\mathrm{IC}_{50}$ concentration was accompanied with an increase of $\mathrm{PGE}_{2}$ production rate. In HaCaT cells G3-BCL induced a low but significant decrease of COX-2 protein expression, although production of $\mathrm{PGE}_{2}$ was significantly higher at $\mathrm{IC}_{50}$ concentration of G3-BCL, which may be the result of COX-1 activity. It has been noticed that in HaCaT cells the COX-2 inhibitor did not fully block $\mathrm{PGE}_{2}$ release [96].
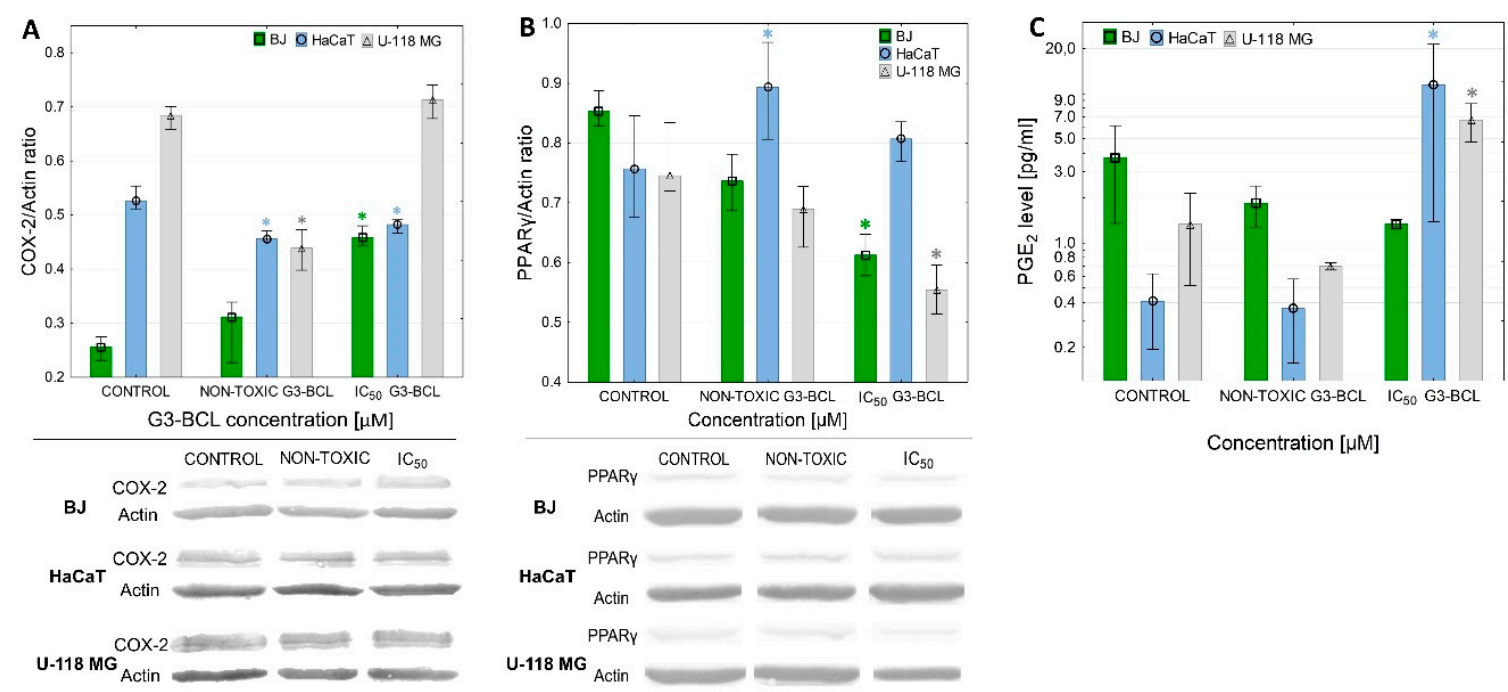

Figure 8. Effect of G3-BCL on expression of COX-2 protein (A), PPAR $\gamma(\mathbf{B})$ and $\mathrm{PGE}_{2}$ production (C) in $\mathrm{BJ}, \mathrm{HaCaT}$ and $\mathrm{U}-118 \mathrm{MG}$ cells after $24 \mathrm{~h}$ treatment with non-toxic $(0.5 \mu \mathrm{M})$ or $\mathrm{IC}_{50}$ concentrations (estimated with XTT assay). Levels of COX-2 protein were calculated against $\beta$-actin and expressed as the percent of the control. Squares indicates medians and whiskers corresponding to the lower (25\%) and upper $(75 \%)$ quartile ranges. ${ }^{*} \mathrm{P}<0.05$ significant difference against control (Kruskal-Wallis test).

Basal levels of PPAR $\gamma$ protein were not significantly different in all three cell lines. The effect of G3-BCL conjugate on PPAR $\gamma$ expression was similar in BJ and U-118 MG cells and resulted in a decrease of the expression of PPAR $\gamma$ protein at $\mathrm{IC}_{50}$ concentrations of conjugate without significant change in HaCaTs. Exposition of various primary human lung tumor cells to celecoxib ( $\mathrm{IC}_{50}$ values between 12 and $43 \mu \mathrm{M}$ ) resulted with apoptosis and upregulation of PPAR $\gamma$ and COX-2 at mRNA and protein levels $[97,98]$. Our results demonstrated that conjugate with both celecoxib and Fmoc-L-Leucine caused apoptosis of U-118 MG cells at much lower concentration $\left(\mathrm{IC}_{50}=1 \mu \mathrm{M}\right)$ with significant decrease of the expression of PPAR $\gamma$. At non-cytotoxic concentration, G3-BCL stimulated U-118 MG proliferation to $120 \%$ of control value with parallel significant decrease of COX-2 expression, followed by its upregulation at $\mathrm{IC}_{50}$ concentration with significant increase of $\mathrm{PGE}_{2}$ production and decrease of proliferation rate. That allowed us to conclude that the pro-apoptotic and anti-migratory effect of G3-BCL conjugate was realized by other mechanisms than the influence of PPAR $\gamma$ expression but it was dependent on COX-2 protein level and high $\mathrm{PGE}_{2}$ production. Comparison of the G3-BCL effect on BJ fibroblasts, having active p53 signaling pathway with p53 mutated U-118 MG cell line, revealed that regardless of p53 status, the significant pro-apoptotic effect was observed. Similar observations were made by Kang et al. with various phenotypes of glioma cell lines [32]. Also, the very different response of $\mathrm{HaCaT}$ cells to G3-BCL confirmed that mutated p53 may result in various sensitivity to effectors of COX-2 and PPAR- $\gamma$ activity. 


\section{Materials and Methods}

\subsection{Dendrimers}

Third generation biotinylated PAMAM G3 dendrimer conjugated with 16 celecoxib molecules and 15 Fmoc-L-Leucine molecules (G3-BCL) and its fluorescein molecule labeled analog (G3-BCLF) were synthetized as described earlier [39].

\subsection{Materials}

Eagle's Minimum Essential Medium (EMEM), Dulbecco's Modified Eagle's Medium (DMEM), fetal bovine serum (FBS), penicillin and streptomycin solution were purchased from ATCC (Manassas, VA, USA). Trypsin-EDTA solution, phosphate-buffered saline (PBS) with and without magnesium and calcium ions, $0.4 \%$ trypan blue solution, fluorescent marker DAPI (4',6-diamidino-2-phenylindole, dihydrochloride), 7-AAD, LysoTracker Red, MitoTracker Deep Red FM, CyQUANT ${ }^{\circledR}$ GR Cell Proliferation Assay Kit were purchased from Thermo Fischer Scientific (Waltham, Massachusetts, USA). XTT sodium salt (2,3-bis [2-methoxy-4-nitro-5-sulfophenyl]-2Htetrazolium-5-carboxanilide inner salt), phenazinemethosulfate(PMS), N-methyl dibenzopyrazine methyl sulfate were purchased from Sigma-Aldrich (St Louis, MO, USA). Rabbit anti PPAR $\gamma$ antibody purchased from WuhanFine Chemicals Co. Ltd. (Wuhan, China), rabbit anti-COX-2 polyclonal antibody from Novus Biologicals (Centennial, Colorado, USA) and goat anti-rabbit IgG $(\mathrm{H}+\mathrm{L})$ antibody from Jackson ImmunoResearch (Philadelphia, PA, USA). ELISA Prostaglandin E2 Parameter Assay Kit was delivered by R\&D Systems (Minneapolis, Minnesota, USA) and DAB reagent by EMD Millipore (Burlington, Massachusetts, USA). Cell culture dishes were from Corning Incorporated (Corning, NY, USA), Greiner (Kremsmünster, Austria) or Nunc (Rochester, New York, USA).

\subsection{Cell cultures}

Human immortalized keratinocytes (HaCaT) obtained from Cell Lines Service (Eppelheim, Germany) and human glioblastoma cell line (U-118 MG) obtained from ATCC (Manassas, VA, USA) were cultured in DMEM (doubling time 24 and $35 \mathrm{~h}$, respectively). Normal fibroblasts BJ purchased from ATCC (doubling time 1.9 days) were grown in EMEM medium. Media were supplemented with $10 \%$ heat-inactivated FBS and $100 \mathrm{U} / \mathrm{mL}$ penicillin, and $100 \mu \mathrm{g} / \mathrm{mL}$ streptomycin. Cells were incubated at $37{ }^{\circ} \mathrm{C}$ in humidified $95 \%$ air with $5 \% \mathrm{CO}_{2}$. Media were changed every $2-3$ days and cells passaging at $70-80 \%$ confluence after treatment with $0.25 \%$ trypsin-EDTA/PBS (calcium and magnesium free). Cell morphology was checked using a Nikon TE2000S Inverted Microscope (Tokyo, Japan) with phase contrast. Number and viability of cells were estimated by trypan blue exclusion test using Automatic Cell Counter TC20TM (Bio-Rad Laboratories, Hercules, CA, USA). All assays were performed in triplicate from three independent experiments.

\subsubsection{Cytotoxicity}

Cytotoxicity of the G3-BCL conjugate was determined with XTT assay that estimate the capacity of mitochondrial oxidoreductases to reduce XTT into water-soluble, formazan product [99]. Cells were seeded in flat-bottom 96-well plates at density $1 \times 10^{4}$ cells/well (BJ and U-118 MG cells) or $2 \times 10^{4}$ (HaCaT cells) and allowed to grow for $24 \mathrm{~h}$. Working solutions of dendrimers $(0.5-4 \mu \mathrm{M})$ were prepared in culture media. The DMSO concentration was adjusted to $0.1 \%$ in all samples that had no significant effect on treated cell lines. After $24 \mathrm{~h}$ exposure to dendrimers, the medium was removed, XTT mixture of $1.7 \mathrm{mM}$ of XTT and $8.3 \mu \mathrm{M}$ of PMS in the complete medium was added (100 $\mu \mathrm{L} /$ well) and the plates were returned to the incubator for $1 \mathrm{~h}$. Then absorbance was measured at 450 and $620 \mathrm{~nm}$ against a blank sample (100 $\mu \mathrm{L}$ of complete growth medium containing XTT and PMS), using a microplate reader ( $\mu$ Quant - BioTek, Winooski, VT, USA). 


\subsubsection{Proliferation}

Cell proliferation after treatment with G3-BCL was determined by CyQUANT ${ }^{\circledR}$ GR Cell Proliferation Assay Kit, a fast and sensitive tool for counting cells in a microplate format. This kit is based on measurement of cellular DNA content using fluorescent dye that enhances its fluorescence after binding to cellular nucleic acids. The DNA content is proportional to the number of cells. Cells were seeded in 96-well clear plates $5 \times 10^{3}$ cells/well. After $24 \mathrm{~h}$, the incubation medium was removed, replaced with a G3-BCL dendrimer at concentrations ranging from 0.125 to $4 \mu \mathrm{M}(200 \mu \mathrm{L} /$ well $)$ and incubated $72 \mathrm{~h}$. Assay was performed according to manufacturer protocol. The fluorescent signal, proportional to the number of cells, was measured with Tecan Infinite M200 PRO Mulitmode Microplate Reader (TECAN Group Ltd., Männedorf, Switzerland) at 360/460 nm. The results were expressed as percentage of the non-treated control.

\subsubsection{Cellular Uptake of G3-BCLF}

Cells were grown in 96-well plates at $2 \times 10^{4}$ cells/well (BJ and U-118 MG) or $4 \times 10^{4}(\mathrm{HaCaT})$. After $24 \mathrm{~h}$, cells were washed with PBS and treated with FITC labeled analog of G3-BCL (G3-BCLF) at $0.1 \mu \mathrm{M}$ concentration in complete EMEM medium for 1, 3, 6 or $24 \mathrm{~h}$. After incubation cells were fixed in 3.7\% formaldehyde and washed with PBS. $600 \mathrm{nM}$ DAPI in PBS was added (100 $\mu \mathrm{L} /$ well) for $1 \mathrm{~h}$ at RT. Fluorescence signal was monitored at 485/530 nm for FITC or 360/460 nm for DAPI using Infinite M200 PRO Multimode Microplate Reader (TECAN Group Ltd., Switzerland). The DAPI fluorescence signals were used to estimate number of cells in each well and to calculate fluorescent signal intensity per cell using the constructed calibration curve.

\subsubsection{Intracellular Location of G3-BCLF}

Cells were seeded in Nunc ${ }^{\mathrm{TM}}$ Lab-Tek $^{\mathrm{TM}}$ 8-well Chambered Coverglass at density $6 \times 10^{4}$ (BJ and $\mathrm{U}-118 \mathrm{MG}$ ) or $1.2 \times 10^{5}$ (HaCaT) in $400 \mu \mathrm{L}$ medium/well. After $48 \mathrm{~h}$, incubation medium was replaced with non-toxic $(0.5 \mu \mathrm{M})$ or equal to $\mathrm{IC}_{50}$ concentrations of $\mathrm{G3}-\mathrm{BCLF}$ as estimated earlier $\left(\mathrm{IC}_{50}=1.25\right.$, 1.29, and 4.49 $\mu \mathrm{M}$ for U-118 MG, BJ and HaCaT, respectively). After $24 \mathrm{~h}$, lysosomes were labelled with $100 \mathrm{~nm}$ solution of LysoTracker Red and mitochondria in parallel samples with $100 \mathrm{~nm}$ MitoTracker Deep Red FM solution in medium for $30 \mathrm{~min}$ at $37^{\circ} \mathrm{C}$. Washing, fixation with $3.7 \%$ formaldehyde and labeling nuclei with $600 \mathrm{~nm}$ DAPI solution were performed as described above. Images were collected using Olympus FV10i confocal microscope with $60 \times$ objective with water immersion (total magnification 120× ). Fluorescence signal was recorded at 405/461 nm for DAPI, 485/535 nm for FITC or 559/600 nm for Lyso or MitoTracker. Pinhole was set for 1 AU (airy unit) and obtained images had an optical section thickness of approximately $1.02 \mu \mathrm{m}$. Images were analyzed using ImageJ software with JACoP plugin and Mander's colocalization coefficients were estimated.

\subsubsection{Cellular ATP Level}

Cells were seeded in 96-well plates at $2 \times 10^{4}$ cells/well for HaCaT and $1 \times 10^{4}$ for U-118 MG and $\mathrm{BJ}$ and incubated for $24 \mathrm{~h}$. Solution of G3-BCL in media with FBS was added at concentration range 0.5-4 $\mu \mathrm{M}(100 \mu \mathrm{L} /$ well). After $24 \mathrm{~h}$. CellTiter-Gloßreagent was added into each well and assay was performed according to manufacturer's protocol. Luminescence was measured with Tecan Infinite M200 PRO Multimode Microplate Reader (Tecan Group Ltd., Switzerland). The DAPI fluorescence signals were used to estimate number of cells in each well and to calculate luminescent signal intensity per one cell from calibration curve. Results were expressed as \% of non-treated control.

\subsubsection{Apoptosis and Late Apoptosis/Necrosis}

To assess active apoptotic (A) process, caspase 3 and 7 activity measurement was performed using the Apo-ONEßHomogenous Caspase-3/7 Assay (Promega, Madison, WI, USA) based on caspase ability to cleave the substrate that emits green fluorescence. Cells were seeded in black 96-well, clear 
bottom plates and treated as described for ATP assay. After $24 \mathrm{~h}$ assay was performed according to manufacturer's protocol. After incubation (120 min, RT) fluorescence was measured at 490/530 nm using Infinite M200 PRO Multimode Microplate Reader. Late apoptosis/necrosis (LA/N) evaluation was performed with 7-amino-actinomycin D dye (7-AAD) [78]. Cells were seeded in a black 96-well, clear bottom plate at $4 \times 10^{4}$ cells/well for HaCaT and $2 \times 10^{4}$ for U-118 MG and BJ cells and treated as described above for caspase assay. 7-AAD $(0.01 \mathrm{mg} / \mathrm{mL}$ in PBS $)$ was added. and after incubation for $30 \mathrm{~min}$ at $37^{\circ} \mathrm{C}$ labeling of nuclei with DAPI was performed as described above. Fluorescence intensity for 7-AAD (546/647 nm) and DAPI (360/460 nm) was measured with Infinite M200 PRO Multimode Microplate Reader. Results were presented as 7-AAD/DAPI signal ratio that corresponds to the percent of LA/N cells in the whole cell population.

\subsubsection{Cell Mobility}

BJ, HaCaT and U-118 cells were seeded into 24 -well plates at $1 \times 10^{5}, 2 \times 10^{5}$ and $2 \times 10^{5}$ cells/well, respectively. Anti-migration properties of G3-BCL were estimated with wound healing assay as described earlier [100].

\subsubsection{COX-2 and PPAR $\gamma$ Expression and $\mathrm{PGE}_{2}$ Production}

After $24 \mathrm{~h}$ treatment with dendrimers $\left(0.5 \mu \mathrm{M}\right.$ non-toxic and $\mathrm{IC}_{50}$ concentrations estimated with XTT assay), proteins from cell cultures were isolated, separated by SDS/PAGE and transferred into PVDF membrane (0.2 $\mu \mathrm{m}$, Bio-Rad, Hercules, CA, USA) as described [39]. Membranes were blocked with $1 \%$ bovine serum albumin (BSA) in TBS/T for $2 \mathrm{~h}$. All incubations were done on a rotary shaker at RT. The membranes were washed once $(10 \mathrm{~min})$ in TBS containing $0.05 \%(v / v)$ Tween 20. Rabbit anti-PPAR $\gamma$ antibody (WuhanFine Chemicals Co. Ltd., Wuhan, China) and rabbit anti-COX-2 polyclonal antibody (Novus Biologicals) were diluted in 1\% BSA-TBS/T, 1:4000 and 1:2000 respectively. The membranes were incubated with primary antibodies for $2 \mathrm{~h}$. After four times washing $(5 \mathrm{~min})$ in TBS/T, secondary peroxidase conjugated antibody (goat anti-rabbit IgG $(\mathrm{H}+\mathrm{L})$ diluted 1:10,000 in TBS; (Jackson ImmunoResearch Laboratories, Baltimore, PA, USA) was added. After $1 \mathrm{~h}$, membranes were washed two times ( $5 \mathrm{~min}$ ) in TBT/T, two times $(5 \mathrm{~min}$ ) in TBS, developed with DAB reagent (10 min, RT) and collected with Epson SX235 scanner. Results were quantified with ImageJ software (US National Institute of Health, Bethesda, MD, USA).

To determine $\mathrm{PGE}_{2}$ level cells were cultured as described in a motility assay. After $24 \mathrm{~h}$ treatment with G3-BCL culture medium was collected and ELISA Prostaglandin E2 Parameter Assay Kit (R\&D Systems) was performed in triplicate according to manufacturer protocol.

\subsubsection{Statistical Analysis}

To estimate differences between G3-BCL treated and non-treated samples the non-parametric Kruskal-Wallis test was used. Mann-Whitney $U$ test was performed to estimate differences in amount of G3-BCLF in cellular compartments at non-toxic or $\mathrm{IC}_{50}$ concentrations. $\mathrm{P}<0.05$ was considered as statistically significant. Calculations were performed with Statistica 12.5 software (StatSoft, Tulsa, OK, USA).

\section{Conclusions}

Comparison of the effect of G3-BCL on expression of COX-2 and PPAR $\gamma$ protein and $\mathrm{PGE}_{2}$ production of three different cell line phenotypes reveal that anti-proliferative, pro-apoptotic and anti-migratory effects of the conjugate was realized by other mechanisms than an influence on PPAR $\gamma$ expression regardless of p53 cell status, but it was dependent on COX-2 protein level and high $\mathrm{PGE}_{2}$ production.

The important achievement was the observation that G3-BCL significantly decreased viability, proliferation and mobility of U-118 MG cells at concentration in range of 1-2 $\mu \mathrm{M}$, many fold lower 
than either drug applied alone. Thus, G3-BCL might be a potential candidate for the targeted, local glioma therapy with limited side effects.

The obtained results also shed light on the use of HaCaT cell line as model for toxicity tests. Many authors emphasize this possibility, but others do not. Our experiments revealed that the profile of $\mathrm{HaCaT}$ response to G3-BCL conjugate differs significantly from normal fibroblasts and U-118 MG glioma cells, which makes them more resistant to the investigated compounds. That confirms the limitation of $\mathrm{HaCaT}$ cells as a model for evaluation of drug toxicity.

Author Contributions: Conceptualization, Ł.U.; methodology, Ł.U., M.M.; validation, Ł.U.; formal analysis, Ł.U.; investigation, Ł.U., M.M., M.P., J.M., S.W., A.F.-R.; resources, Ł.U., S.W.; writing-original draft preparation, Ł.U., E.W.-R. M.P.; writing—review and editing, E.W.-R., Ł.U., S.W.; visualization, Ł.U.; supervision Ł.U.; project administration, Ł.U.; funding acquisition, Ł.U., S.W.

Funding: This research was funded by National Science Centre, Poland, grant number 2014/13/D/NZ3/02825.

Acknowledgments: We gratefully acknowledge Stanislaw Orkisz from University of Rzeszow, for kindly enabling us to perform measurements using the confocal microscope.

Conflicts of Interest: The authors declare no conflict of interest.

\section{References}

1. Ohgaki, H.; Kleihues, P. Epidemiology and etiology of gliomas. Acta Neuropathol. 2005, 109, 93-108. [CrossRef] [PubMed]

2. Ostrom, Q.T.; Bauchet, L.; Davis, F.G.; Deltour, I.; Fisher, J.L.; Langer, C.E.; Pekmezci, M.; Schwartzbaum, J.A.; Turner, M.C.; Walsh, K.M.; et al. The epidemiology of glioma in adults: A "state of the science" review. Neuro Oncol. 2014, 16, 896-913. [CrossRef] [PubMed]

3. Demuth, T.; Berens, M.E. Molecular Mechanisms of Glioma Cell Migration and Invasion. J. Neurooncol. 2004, 70, 217-228. [CrossRef] [PubMed]

4. Chamberlain, M.C. Temozolomide: Therapeutic limitations in the treatment of adult high-grade gliomas. Expert Rev. Neurother. 2010, 10, 1537-1544. [CrossRef] [PubMed]

5. Oshiro, S.; Tsugu, H.; Komatsu, F.; Ohmura, T.; Ohta, M.; Sakamoto, S.; Fukushima, T.; Inoue, T. Efficacy of Temozolomide Treatment in Patients with High-grade Glioma. Anticancer Res. 2009, 29, 911-917. [PubMed]

6. Johnson, D.R.; O'Neill, B.P. Glioblastoma survival in the United States before and during the temozolomide era. J. Neurooncol. 2012, 107, 359-364. [CrossRef] [PubMed]

7. Pan, I.-W.; Ferguson, S.D.; Lam, S. Patient and treatment factors associated with survival among adult glioblastoma patients: A USA population-based study from 2000-2010. J. Clin. Neurosci. 2015, 22, 1575-1581. [CrossRef]

8. Crespo, I.; Vital, A.L.; Gonzalez-Tablas, M.; del Carmen Patino, M.; Otero, A.; Lopes, M.C.; de Oliveira, C.; Domingues, P.; Orfao, A.; Tabernero, M.D. Molecular and Genomic Alterations in Glioblastoma Multiforme. Am. J. Pathol. 2015, 185, 1820-1833. [CrossRef]

9. Newcomb, E.W.; Madonia, W.J.; Pisharody, S.; Lang, F.F.; Koslow, M.; Miller, D.C. A Correlative Study of p53 Protein Alteration and p53 Gene Mutation in Glioblastoma Multiforme. Brain Pathol. 1993, 3, $229-235$. [CrossRef]

10. Verhaak, R.G.W.; Hoadley, K.A.; Purdom, E.; Wang, V.; Qi, Y.; Wilkerson, M.D.; Miller, C.R.; Ding, L.; Golub, T.; Mesirov, J.P.; et al. Integrated Genomic Analysis Identifies Clinically Relevant Subtypes of Glioblastoma Characterized by Abnormalities in PDGFRA, IDH1, EGFR, and NF1. Cancer Cell 2010, 17, 98-110. [CrossRef]

11. Zhou, G.; Liu, Z.; Myers, J.N. TP53 Mutations in Head and Neck Squamous Cell Carcinoma and Their Impact on Disease Progression and Treatment Response. J. Cell. Biochem. 2016, 117, 2682-2692. [CrossRef] [PubMed]

12. Zhang, Y.; Dube, C.; Gibert, M.; Cruickshanks, N.; Wang, B.; Coughlan, M.; Yang, Y.; Setiady, I.; Deveau, C.; Saoud, K.; et al. The p53 Pathway in Glioblastoma. Cancers 2018, 10, 297. [CrossRef] [PubMed]

13. Alphandéry, E. Glioblastoma Treatments: An Account of Recent Industrial Developments. Front. Pharmacol. 2018, 9, 879. [CrossRef]

14. Ivanov, V.N.; Wu, J.; Hei, T.K. Regulation of human glioblastoma cell death by combined treatment of cannabidiol, $\gamma$-radiation and small molecule inhibitors of cell signaling pathways. Oncotarget 2017, 8 , 74068-74095. [CrossRef] [PubMed] 
15. Buchanan, F.G.; DuBois, R.N. Connecting COX-2 and Wnt in cancer. Cancer Cell 2006, 9, 6-8. [CrossRef] [PubMed]

16. Wu, M.; Guan, J.; Li, C.; Gunter, S.; Nusrat, L.; Ng, S.; Dhand, K.; Morshead, C.; Kim, A.; Das, S. Aberrantly activated Cox-2 and Wnt signaling interact to maintain cancer stem cells in glioblastoma. Oncotarget 2017, 8, 82217-82230. [CrossRef] [PubMed]

17. Lecarpentier, Y.; Claes, V.; Vallée, A.; Hébert, J.-L. Thermodynamics in cancers: Opposing interactions between PPAR gamma and the canonical WNT/beta-catenin pathway. Clin. Trans. Med. 2017, 6, 14. [CrossRef]

18. Vallée, A.; Lecarpentier, Y.; Guillevin, R.; Vallée, J.-N. Opposite Interplay between the Canonical WNT/ $\beta$-Catenin Pathway and PPAR Gamma: A Potential Therapeutic Target in Gliomas. Neurosci. Bull. 2018, 34, 573-588. [CrossRef]

19. Vallée, A.; Lecarpentier, Y. Crosstalk between Peroxisome Proliferator-Activated Receptor Gamma and the Canonical WNT/ $\beta$-Catenin Pathway in Chronic Inflammation and Oxidative Stress during Carcinogenesis. Front. Immunol. 2018, 9, 745. [CrossRef]

20. Shono, T.; Tofilon, P.J.; Bruner, J.M.; Owolabi, O.; Lang, F.F. Cyclooxygenase-2 Expression in Human Gliomas: Prognostic Significance and Molecular Correlations. Cancer Res. 2001, 61, 4375-4381.

21. New, P. Cyclooxygenase in the Treatment of Glioma: Its Complex Role in Signal Transduction. Cancer Control 2004, 11, 152-164. [CrossRef] [PubMed]

22. Rizzo, M.T. Cyclooxygenase-2 in oncogenesis. Clin. Chim. Acta 2011, 412, 671-687. [CrossRef] [PubMed]

23. Qiu, J.; Shi, Z.; Jiang, J. Cyclooxygenase-2 in glioblastoma multiforme. Drug Discov. Today 2017, 22, 148-156. [CrossRef] [PubMed]

24. Tegeder, I.; Pfeilschifter, J.; Geisslinger, G. Cyclooxygenase-independent actions of cyclooxygenase inhibitors. FASEB J. 2001, 15, 2057-2072. [CrossRef]

25. Schönthal, A.H. Direct non-cyclooxygenase-2 targets of celecoxib and their potential relevance for cancer therapy. Br. J. Cancer 2007, 97, 1465-1468. [CrossRef]

26. Grösch, S.; Maier, T.J.; Schiffmann, S.; Geisslinger, G. Cyclooxygenase-2 (COX-2)-Independent Anticarcinogenic Effects of Selective COX-2 Inhibitors. J. Natl. Cancer Inst. 2006, 98, 736-747. [CrossRef]

27. Barker, N.; Clevers, H. Mining the Wnt pathway for cancer therapeutics. Nat. Rev. Drug Discov. 2006, 5, 997-1014. [CrossRef]

28. Ricciotti, E.; FitzGerald, G.A. Prostaglandins and Inflammation. Arterioscler. Thromb. Vasc. Biol. 2011, 31, 986-1000. [CrossRef]

29. Forman, B.M.; Tontonoz, P.; Chen, J.; Brun, R.P.; Spiegelman, B.M.; Evans, R.M. 15-Deoxy-delta 12, 14-prostaglandin J2 is a ligand for the adipocyte determination factor PPAR gamma. Cell 1995, 83, 803-812. [CrossRef]

30. Finch, E.R.; Tukaramrao, D.B.; Goodfield, L.L.; Quickel, M.D.; Paulson, R.F.; Prabhu, K.S. Activation of PPAR $\gamma$ by endogenous prostaglandin $\mathrm{J} 2$ mediates the antileukemic effect of selenium in murine leukemia. Blood 2017, 129, 1802-1810. [CrossRef]

31. Knopfová, L.; Šmarda, J. The use of Cox-2 and PPAR $\gamma$ signaling in anti-cancer therapies (Review). Exp. Ther. Med. 2010, 1, 257-264. [CrossRef] [PubMed]

32. Kang, K.B.; Zhu, C.; Yong, S.K.; Gao, Q.; Wong, M.C. Enhanced sensitivity of celecoxib in human glioblastoma cells: Induction of DNA damage leading to p53-dependent G1 cell cycle arrest and autophagy. Mol. Cancer 2009, 8, 66. [CrossRef] [PubMed]

33. Chatterjee, A.; Mondal, P.; Ghosh, S.; Mehta, V.S.; Sen, E. PPAR $\gamma$ regulated CIDEA affects pro-apoptotic responses in glioblastoma. Cell Death Discov. 2015, 1, 1-9. [CrossRef] [PubMed]

34. Strakova, N.; Ehrmann, J.; Dzubak, P.; Bouchal, J.; Kolar, Z. The Synthetic Ligand of Peroxisome Proliferator-Activated Receptor- $\gamma$ Ciglitazone Affects Human Glioblastoma Cell Lines. J. Pharmacol. Exp. Ther. 2004, 309, 1239-1247. [CrossRef]

35. Im, C.-N. Combination Treatment with PPAR $\gamma$ Ligand and Its Specific Inhibitor GW9662 Downregulates BIS and 14-3-3 Gamma, Inhibiting Stem-Like Properties in Glioblastoma Cells. Available online: https: //www.hindawi.com/journals/bmri/2017/5832824/ (accessed on 27 September 2019).

36. Grommes, C.; Landreth, G.E.; Sastre, M.; Beck, M.; Feinstein, D.L.; Jacobs, A.H.; Schlegel, U.; Heneka, M.T. Inhibition of in Vivo Glioma Growth and Invasion by Peroxisome Proliferator-Activated Receptor $\gamma$ Agonist Treatment. Mol. Pharmacol. 2006, 70, 1524-1533. [CrossRef] 
37. Grommes, C.; Conway, D.S.; Alshekhlee, A.; Barnholtz-Sloan, J.S. Inverse association of PPAR $\gamma$ agonists use and high grade glioma development. J. Neurooncol. 2010, 100, 233-239. [CrossRef]

38. Rocchi, S.; Picard, F.; Vamecq, J.; Gelman, L.; Potier, N.; Zeyer, D.; Dubuquoy, L.; Bac, P.; Champy, M.F.; Plunket, K.D.; et al. A unique PPARgamma ligand with potent insulin-sensitizing yet weak adipogenic activity. Mol. Cell 2001, 8,737-747. [CrossRef]

39. Uram, Ł.; Filipowicz, A.; Misiorek, M.; Pieńkowska, N.; Markowicz, J.; Wałajtys-Rode, E.; Wołowiec, S. Biotinylated PAMAM G3 dendrimer conjugated with celecoxib and/or Fmoc-l-Leucine and its cytotoxicity for normal and cancer human cell lines. Eur. J. Pharm. Sci. 2018, 124, 1-9. [CrossRef]

40. Michael, M.S.; Badr, M.Z.; Badawi, A.F. Inhibition of cyclooxygenase-2 and activation of peroxisome proliferator-activated receptor- $\gamma$ synergistically induces apoptosis and inhibits growth of human breast cancer cells. Int. J. Mol. Med. 2003, 11, 733-736. [CrossRef]

41. Mustafa, A.; Kruger, W.D. Suppression of Tumor Formation by a Cyclooxygenase-2 Inhibitor and a Peroxisome Proliferator-Activated Receptor $\gamma$ Agonist in an In vivo Mouse Model of Spontaneous Breast Cancer. Clin. Cancer Res. 2008, 14, 4935-4942. [CrossRef]

42. Sun, W.-H.; Chen, G.-S.; Ou, X.-L.; Yang, Y.; Luo, C.; Zhang, Y.; Shao, Y.; Xu, H.-C.; Xiao, B.; Xue, Y.-P.; et al. Inhibition of COX-2 and activation of peroxisome proliferator-activated receptor gamma synergistically inhibits proliferation and induces apoptosis of human pancreatic carcinoma cells. Cancer Lett. 2009, 275, 247-255. [CrossRef] [PubMed]

43. Ellis, H.P.; Kurian, K.M. Biological Rationale for the Use of PPAR $\gamma$ Agonists in Glioblastoma. Front. Oncol. 2014, 4, 52. [CrossRef] [PubMed]

44. Scatena, R.; Bottoni, P.; Martorana, G.E.; Ferrari, F.; De, P.S.; Rossi, C.; Giardina, B. Mitochondrial respiratory chain dysfunction, a non-receptor-mediated effect of synthetic PPAR-ligands: Biochemical and pharmacological implications. Biochem. Biophys. Res. Commun. 2004, 319, 967-973. [CrossRef] [PubMed]

45. Scatena, R.; Bottoni, P.; Giardina, B. Mitochondria, PPARs, and Cancer: Is Receptor-Independent Action of PPAR Agonists a Key? PPAR Res. 2008, 2008, 256251. [CrossRef]

46. Walker, C.; Biasucci, L.M. Cardiovascular safety of non-steroidal anti-inflammatory drugs revisited. Postgrad. Med. 2018, 130, 55-71. [CrossRef]

47. Whilding, L.M.; Maher, J. CAR T-cell immunotherapy: The path from the by-road to the freeway? Mol. Oncol. 2015, 9, 1994-2018. [CrossRef]

48. Jahan, S.T.; Sadat, S.M.A.; Walliser, M.; Haddadi, A. Targeted Therapeutic Nanoparticles: An Immense Promise to Fight against Cancer. J. Drug Deliv. 2017, 2017, 9090325. [CrossRef]

49. Jain, K.; Kesharwani, P.; Gupta, U.; Jain, N.K. Dendrimer toxicity: Let's meet the challenge. Int. J. Pharm. 2010, 394, 122-142. [CrossRef]

50. Dwivedi, N.; Shah, J.; Mishra, V.; Amin, M.C.I.M.; Iyer, A.K.; Tekade, R.K.; Kesharwani, P. Dendrimer-mediated approaches for the treatment of brain tumor. J. Biomater. Sci. Polym. Ed. 2016, 27, 557-580. [CrossRef]

51. Florendo, M.; Figacz, A.; Srinageshwar, B.; Sharma, A.; Swanson, D.; Dunbar, G.L.; Rossignol, J. Use of Polyamidoamine Dendrimers in Brain Diseases. Molecules 2018, 23, 2238. [CrossRef]

52. Karim, R.; Palazzo, C.; Evrard, B.; Piel, G. Nanocarriers for the treatment of glioblastoma multiforme: Current state-of-the-art. J. Control Release 2016, 227, 23-37. [CrossRef]

53. Sarin, H.; Kanevsky, A.S.; Wu, H.; Brimacombe, K.R.; Fung, S.H.; Sousa, A.A.; Auh, S.; Wilson, C.M.; Sharma, K.; Aronova, M.A.; et al. Effective transvascular delivery of nanoparticles across the blood-brain tumor barrier into malignant glioma cells. J. Transl. Med. 2008, 6, 80. [CrossRef] [PubMed]

54. Gonawala, S.; Ali, M.M. Application of Dendrimer-based Nanoparticles in Glioma Imaging. J. Nanomed. Nanotechnol. 2017, 8. [CrossRef]

55. Castro, R.I.; Forero-Doria, O.; Guzmán, L.; Castro, R.I.; Forero-Doria, O.; Guzmán, L. Perspectives of Dendrimer-based Nanoparticles in Cancer Therapy. Anais Academia Brasileira Ciências 2018, 90, 2331-2346. [CrossRef] [PubMed]

56. Tripodo, G.; Mandracchia, D.; Collina, S.; Rui, M.; Rossi, D. New Perspectives in Cancer Therapy: The Biotin-Antitumor Molecule Conjugates. Med. Chem. 2014, 8, 1-4.

57. Holban, A.M.; Grumezescu, A.M. Nanoarchitectonics for Smart Delivery and Drug Targeting, 1st ed.; Elsevier: Amsterdam, Netherlands, 2016; ISBN 978-0-323-47347-7. 
58. Spector, R.; Mock, D.M. Biotin transport and metabolism in the central nervous system. Neurochem. Res. 1988, 13, 213-219. [CrossRef]

59. Hemmer, R.; Hall, A.; Spaulding, R.; Rossow, B.; Hester, M.; Caroway, M.; Haskamp, A.; Wall, S.; Bullen, H.A.; Morris, C.; et al. Analysis of Biotinylated Generation 4 Poly(amidoamine) (PAMAM) Dendrimer Distribution in the Rat Brain and Toxicity in a Cellular Model of the Blood-Brain Barrier. Molecules 2013, 18, 11537-11552. [CrossRef]

60. Chen, S.; Zhao, X.; Chen, J.; Chen, J.; Kuznetsova, L.; Wong, S.S.; Ojima, I. Mechanism-Based Tumor-Targeting Drug Delivery System. Validation of Efficient Vitamin Receptor-Mediated Endocytosis and Drug Release. Bioconj. Chem. 2010, 21, 979-987. [CrossRef]

61. Veszelka, S.; Meszaros, M.; Kiss, L.; Kota, Z.; Pali, T.; Hoyk, Z.; Bozso, Z.; Fulop, L.; Toth, A.; Rakhely, G.; et al. Biotin and Glutathione Targeting of Solid Nanoparticles to Cross Human Brain Endothelial Cells. Curr. Pharm. Des. 2017, 23, 4198-4205. [CrossRef]

62. Uram, Ł.; Szuster, M.; Filipowicz, A.; Zaręba, M.; Wałajtys-Rode, E.; Wołowiec, S. Cellular uptake of glucoheptoamidated poly(amidoamine) PAMAM G3 dendrimer with amide-conjugated biotin, a potential carrier of anticancer drugs. Bioorg. Med. Chem. 2017, 25, 706-713. [CrossRef]

63. Sareddy, G.R.; Geeviman, K.; Ramulu, C.; Babu, P.P. The nonsteroidal anti-inflammatory drug celecoxib suppresses the growth and induces apoptosis of human glioblastoma cells via the NF-kB pathway. J. Neurooncol. 2012, 106, 99-109. [CrossRef] [PubMed]

64. Li, L.-Y.; Xiao, J.; Liu, Q.; Xia, K. Parecoxib inhibits glioblastoma cell proliferation, migration and invasion by upregulating miRNA-29c. Biol. Open 2017, 6, 311-316. [CrossRef] [PubMed]

65. Van der Pauw, M.T.; den Bos, T.V.; Everts, V.; Beertsen, W. Phagocytosis of Fibronectin and Collagens Type I, III, and V by Human Gingival and Periodontal Ligament Fibroblasts In Vitro. J. Periodontol. 2001, 72, 1340-1347. [CrossRef] [PubMed]

66. Götz, C.; Pfeiffer, R.; Tigges, J.; Ruwiedel, K.; Hübenthal, U.; Merk, H.F.; Krutmann, J.; Edwards, R.J.; Abel, J.; Pease, C.; et al. Xenobiotic metabolism capacities of human skin in comparison with a 3D-epidermis model and keratinocyte-based cell culture as in vitro alternatives for chemical testing: Phase II enzymes. Exp. Dermatol. 2012, 21, 364-369. [CrossRef]

67. Cheng, Y. Dendrimer-Based Drug Delivery Systems: From Theory to Practice; John Wiley \& Sons: Hoboken, NJ, USA, 2012; ISBN 978-0-470-46005-4.

68. Zhang, J.; Liu, D.; Zhang, M.; Sun, Y.; Zhang, X.; Guan, G.; Zhao, X.; Qiao, M.; Chen, D.; Hu, H. The cellular uptake mechanism, intracellular transportation, and exocytosis of polyamidoamine dendrimers in multidrug-resistant breast cancer cells. Int. J. Nanomed. 2016, 11, 3677-3690. [CrossRef]

69. Albertazzi, L.; Serresi, M.; Albanese, A.; Beltram, F. Dendrimer Internalization and Intracellular Trafficking in Living Cells. Mol. Pharm. 2010, 7, 680-688. [CrossRef]

70. Kitchens, K.M.; Foraker, A.B.; Kolhatkar, R.B.; Swaan, P.W.; Ghandehari, H. Endocytosis and interaction of poly (amidoamine) dendrimers with Caco-2 cells. Pharm. Res. 2007, 24, 2138-2145. [CrossRef]

71. Kitchens, K.M.; Kolhatkar, R.B.; Swaan, P.W.; Ghandehari, H. Endocytosis inhibitors prevent poly(amidoamine) dendrimer internalization and permeability across Caco-2 cells. Mol. Pharm. 2008, 5, 364-369. [CrossRef]

72. Yellepeddi, V.K.; Kumar, A.; Palakurthi, S. Biotinylated poly(amido)amine (PAMAM) dendrimers as carriers for drug delivery to ovarian cancer cells in vitro. Anticancer Res. 2009, 29, 2933-2943.

73. Zempleni, J. Uptake, Localization, and Noncarboxylase Roles of Biotin. Annu. Rev. Nutr. 2005, 25, $175-196$. [CrossRef]

74. Galluzzi, L.; Morselli, E.; Kepp, O.; Vitale, I.; Rigoni, A.; Vacchelli, E.; Michaud, M.; Zischka, H.; Castedo, M.; Kroemer, G. Mitochondrial gateways to cancer. Mol. Aspects Med. 2010, 31, 1-20. [CrossRef] [PubMed]

75. Shao, D.; Kan, M.; Qiao, P.; Pan, Y.; Wang, Z.; Xiao, X.; Li, J.; Chen, L. Celecoxib induces apoptosis via a mitochondria-dependent pathway in the $\mathrm{H} 22$ mouse hepatoma cell line. Mol. Med. Rep. 2014, 10, 2093-2098. [CrossRef] [PubMed]

76. Fan, W.; Evans, R. PPARs and ERRs: Molecular mediators of mitochondrial metabolism. Curr. Opin. Cell Biol. 2015, 33, 49-54. [CrossRef] [PubMed]

77. Schnurr, B.; Ahrens, T.; Regenass, U. Optical Assays in Drug Discovery. In Comprehensive Medicinal Chemistry II; Elsevier: Amsterdam, Netherlands, 2007; pp. 577-598. ISBN 978-0-08-045044-5.

78. Zimmermann, M.; Meyer, N. Annexin V/7-AAD staining in keratinocytes. Methods Mol. Biol. 2011, 740, 57-63. 
79. Eguchi, Y.; Shimizu, S.; Tsujimoto, Y. Intracellular ATP levels determine cell death fate by apoptosis or necrosis. Cancer Res. 1997, 57, 1835-1840.

80. Chen, Q.; Kang, J.; Fu, C. The independence of and associations among apoptosis, autophagy, and necrosis. Signal Transduct. Target Ther. 2018, 3, 18. [CrossRef]

81. Zamaraeva, M.V.; Sabirov, R.Z.; Maeno, E.; Ando-Akatsuka, Y.; Bessonova, S.V.; Okada, Y. Cells die with increased cytosolic ATP during apoptosis: A bioluminescence study with intracellular luciferase. Cell Death Differ. 2005, 12, 1390-1397. [CrossRef]

82. Los, M.; Mozoluk, M.; Ferrari, D.; Stepczynska, A.; Stroh, C.; Renz, A.; Herceg, Z.; Wang, Z.-Q.; Schulze-Osthoff, K. Activation and Caspase-mediated Inhibition of PARP: A Molecular Switch between Fibroblast Necrosis and Apoptosis in Death Receptor Signaling. MBoC 2002, 13, 978-988. [CrossRef]

83. Furnari, F.B.; Fenton, T.; Bachoo, R.M.; Mukasa, A.; Stommel, J.M.; Stegh, A.; Hahn, W.C.; Ligon, K.L.; Louis, D.N.; Brennan, C.; et al. Malignant astrocytic glioma: Genetics, biology, and paths to treatment. Genes Dev. 2007, 21, 2683-2710. [CrossRef]

84. Nzengue, Y.; Steiman, R.; Guiraud, P. Characterization of the cell death induced by cadmium in HaCaT and C6 cell lines. Free Radic. Res. 2008, 42, 142-153. [CrossRef]

85. Henseleit, U.; Rosenbach, T.; Kolde, G. Induction of apoptosis in human HaCaT keratinocytes. Arch. Dermatol. Res. 1996, 288, 676-683. [CrossRef]

86. El Darzi, E.; Bazzi, S.; Daoud, S.; Echtay, K.S.; Bahr, G.M. Differential regulation of surface receptor expression, proliferation, and apoptosis in HaCaT cells stimulated with interferon- $\gamma$, interleukin-4, tumor necrosis factor- $\alpha$, or muramyl dipeptide. Int. J. Immunopathol. Pharmacol. 2017, 30, 130-145. [CrossRef]

87. Lehman, T.A.; Modali, R.; Boukamp, P.; Stanek, J.; Bennett, W.P.; Welsh, J.A.; Metcalf, R.A.; Stampfer, M.R.; Fusenig, N.; Rogan, E.M. p53 mutations in human immortalized epithelial cell lines. Carcinogenesis 1993, 14, 833-839. [CrossRef]

88. Henseleit, U.; Zhang, J.; Wanner, R.; Haase, I.; Kolde, G.; Rosenbach, T. Role of p53 in UVB-Induced Apoptosis in Human HaCaT Keratinocytes. J. Investig. Dermatol. 1997, 109, 722-727. [CrossRef]

89. Barlow, M.; Edelman, M.; Glick, R.D.; Steinberg, B.M.; Soffer, S.Z. Celecoxib inhibits invasion and metastasis via a cyclooxygenase 2 -independent mechanism in an in vitro model of Ewing sarcoma. J. Pediatr. Surg. 2012, 47, 1223-1227. [CrossRef]

90. Behr, C.A.; Hesketh, A.J.; Barlow, M.; Glick, R.D.; Symons, M.; Steinberg, B.M.; Soffer, S.Z. Celecoxib inhibits Ewing sarcoma cell migration via actin modulation. J. Surg. Res. 2015, 198, 424-433. [CrossRef]

91. Patel, M.I.; Subbaramaiah, K.; Du, B.; Chang, M.; Yang, P.; Newman, R.A.; Cordon-Cardo, C.; Thaler, H.T.; Dannenberg, A.J. Celecoxib inhibits prostate cancer growth: Evidence of a cyclooxygenase-2-independent mechanism. Clin. Cancer Res. 2005, 11, 1999-2007. [CrossRef]

92. Lee, E.J.; Choi, E.M.; Kim, S.R.; Park, J.H.; Kim, H.; Ha, K.S.; Kim, Y.M.; Kim, S.S.; Choe, M.; Kim, J.-I.; et al. Cyclooxygenase-2 promotes cell proliferation, migration and invasion in U2OS human osteosarcoma cells. Exp. Mol. Med. 2007, 39, 469-476. [CrossRef]

93. Zhou, J.-Y.; Li, X.-Q.; Xu, X.-T.; Wang, L.-L.; Qin, S.-B.; Tu, Y. Celecoxib inhibits the proliferation and migration of human glioblastoma SHG-44 cells in vitro. Tumor 2010, 30, 913-916.

94. Seufert, S.; Coras, R.; Tränkle, C.; Zlotos, D.P.; Blümcke, I.; Tatenhorst, L.; Heneka, M.T.; Hahnen, E. PPAR Gamma Activators: Off-Target Against Glioma Cell Migration and Brain Invasion. PPAR Res. 2008, 2008, 513943. [CrossRef]

95. Kim, Y. Regulation of Cell Proliferation and Migration in Glioblastoma: New Therapeutic Approach. Front. Oncol. 2013, 3, 53. [CrossRef]

96. Hu, Y.-P.; Peng, Y.-B.; Zhang, Y.-F.; Wang, Y.; Yu, W.-R.; Yao, M.; Fu, X.-J. Reactive Oxygen Species Mediated Prostaglandin E2 Contributes to Acute Response of Epithelial Injury. Oxid. Med. Cell Longev. 2017, 2017, 4123854. [CrossRef]

97. Zhang, M.; Xu, Z.-G.; Shi, Z.; Shao, D.; Li, O.; Li, W.; Li, Z.-J.; Wang, K.-Z.; Chen, L. Inhibitory effect of celecoxib in lung carcinoma by regulation of cyclooxygenase-2/cytosolic phospholipase A2 and peroxisome proliferator-activated receptor gamma. Mol. Cell. Biochem. 2011, 355, 233-240. [CrossRef]

98. Ramer, R.; Walther, U.; Borchert, P.; Laufer, S.; Linnebacher, M.; Hinz, B. Induction but not inhibition of COX-2 confers human lung cancer cell apoptosis by celecoxib. J. Lipid Res. 2013, 54, 3116-3129. [CrossRef] 
99. Roehm, N.W.; Rodgers, G.H.; Hatfield, S.M.; Glasebrook, A.L. An improved colorimetric assay for cell proliferation and viability utilizing the tetrazolium salt XTT. J. Immunol. Methods 1991, 142, 257-265. [CrossRef]

100. Uram, Ł.; Szuster, M.; Misiorek, M.; Filipowicz, A.; Wołowiec, S.; Wałajtys-Rode, E. The effect of G3 PAMAM dendrimer conjugated with B-group vitamins on cell morphology, motility and ATP level in normal and cancer cells. Eur. J. Pharm. Sci. 2017, 102, 275-283. [CrossRef]

Sample Availability: Samples of the compounds G3-BCL are available from the authors.

(C) 2019 by the authors. Licensee MDPI, Basel, Switzerland. This article is an open access article distributed under the terms and conditions of the Creative Commons Attribution (CC BY) license (http://creativecommons.org/licenses/by/4.0/). 